\title{
Formation of Artistic Orientations of Senior Pupils in the Context of Modern Methodological Approaches
}

\author{
Pankiv Liudmyla \\ Candidate of Pedagogical Sciences, PhD in Pedagogy \\ Dragomanov National Pedagogical University (Kyiv, Ukraine)
}

\begin{abstract}
The article describes the methodological approaches of forming the artistic orientations of senior pupils in secondary school. The importance of the Art education of senior pupils as an opportunity of awareness of the value of human experience is identified. Personal perception of art values is provided by artistic orientations in the world of culture. The essence of the category "value" is given. The author presents methodological approaches of forming the artistic orientations of senior pupils. Methodological landmarks of the Art in secondary school in the context of the universal, national and personal values are defined. Proved that of forming the artistic orientations of senior pupils in art education opens opportunities for the inner development of young people in the way of using arts as a means of the senior pupils' personal development.
\end{abstract}

Key words: art, artistic education, methodological approaches, values, senior pupils.

Постановка проблеми. Розвиток сучасної мистецької освіти все більш спрямовується на формування особистості, ii духовних орієнтирів, світогляду, гуманістичного ставлення до навколишньої дійсності.

Мистецтво завжди було зверненим до людини, до іiі внутрішнього світу, транслюючи духовні цінності та ідеали багатьох поколінь. Теоретики мистецької освіти (Е. Абдуллін, Л. Масол, О. Отич, Г. Падалка, О. Рудницька, О. Щолокова та ін.) наголошують, що художні образи безпосередньо звернені до сенсорної сфери людини, ii емоцій та почуттів, спонукають до їх особистісного переживання і тим самим забезпечують чуттєвість та глибинність впливу на становлення особистості, формування іiі свідомості. Тож, глибина сприймання мистецтва регулюється потребою реципієнта у спілкуванні з художніми образами, що в свою чергу загострює питання вибіркового ставлення особистості до них як художніх цінностей, усвідомлення власних неповторних переживань емоційного змісту художніх творів, індивідуального оцінювання художніх образів. Надання переваги тим чи іншим видам мистецтва (музика, хореографія, живопис, література, театр та ін.), його жанрам та напрямкам забезпечується багатьма чинниками індивідуального сприйняття (художні нахили, 
здібності та ін.) та художніми орієнтаціями особистості, що визначають художні потреби, інтереси, ідеали, уподобання.

Саме через художні орієнтації актуалізуються художні та естетичні цінності, що є важливим чинником духовного розвитку особистості. 3 огляду на це, формування художніх орієнтацій учнів $є$ важливою проблемою сучасної мистецької освіти. Особливого значення вона набуває в мистецькому навчанні старшокласників, коли активно формується особистість, ऑiі внутрішній світ, життєві цінності та ідеали, загострюються питання самовизначення.

Формування художніх орієнтацій старшокласників - складний i неоднозначний процес, потребує значних зусиль педагога щодо широкого ознайомлення учнів із явищами художньої культури, зосередженості на індивідуальних реакціях особистості на художні образи, розвитку критичного мислення в оцінюванні художніх творів. При цьому, ефективність педагогічного процесу, як наголошують вчені-педагоги (В. Андрущенко, С. Гончаренко, В. Краєвський, Т. Кун, В. Курило, О. Сухомлинська, С. Хриков та ін.), забезпечується визначеністю та обгрунтованістю методології досліджуваного явища, від якої залежить вибір стратегій і методів педагогічної роботи означеного напрямку.

Мета статті - розглянути сучасні методологічні підходи щодо формування художніх орієнтацій старшокласників в умовах мистецької освіти в загальноосвітній школі.

Виклад основного матеріалу. Художніх орієнтації є феноменом, що забезпечує вибірковість ставлення особистості до того чи іншого різновиду, жанру мистецтва, художньої діяльності, зумовлюється художньо-естетичними потребами, художньою інформованістю, сформованістю почуттєвої сфери, наявністю досвіду спілкування 3 художніми образами мистецтва. Художні орієнтації становлять, 3 одного боку взаємозв'язок елементів психологічної спрямованості особистості (інтересів, смаків, потреб, уподобань, установок), а з іншого - виступають як відображення певного художнього досвіду, поінформованості в царині мистецтва та художньої культури. Отже, художні орієнтації створюють змістовну сторону спрямованості особистості до вивчення різноманіття мистецтва i виражають внутрішню характеристику особистісного ставлення до художніх образів. 
Ефективність формування художніх орієнтацій старшокласників значною мірою обумовлюється обгрунтуванням методологічних підходів, що визначають головні ідеї та стратегії педагогічного процесу, як «принципів і способів організації і побудови теоретичної і практичної діяльності» [1, с. 163]. За словами О. Отич, «методологічні підходи дозволяють не лише проаналізувати й описати досліджуваний процес, виявивши певний аспект розуміння сутності досліджуваних освітніх явищ, але й передбачити можливі варіанти його розвитку, ідентифікувати феномени освіти, використовуючи інформаційні модулі, що становлять їі змістове ядро й визначають наукові та світоглядні орієнтири їі реалізації» [2, с. 180].

У мистецькій педагогіці існує велика кількість методологічних підходів, які визначають спрямованість досліджень різноманітної художньо-освітньої проблематики та відображають специфіку педагогічних явищ. Оскільки мистецьке навчання має по своїй суті особистісне спрямування, базовим підходом у педагогічних дослідженнях мистецької галузі є особистісний, який грунтується на положеннях гуманістичної парадигми освіти, що охоплює ідеї людиноцентризму, а учня визнає центром освітнього процесу. Формування художніх орієнтацій старшокласників з позицій цього підходу розглядається як процес художнього розвитку особистості учня, виявлення та реалізації його творчого потенціалу через залучення до різних видів художньої творчості.

Важливим методологічним підходом у мистецько-педагогічних дослідженнях є культурологічний, що наповнює мистецьку освіту культурними смислами, орієнтує навчальний процес на широке ознайомлення учнів 3 культурними цінностями мистецтва, передбачає спонукання учнів до пізнання різних художніх напрямків та різновидів мистецтва, систематичного збагачення і розширення мистецького досвіду як засобу формування особистісної культури. У контексті культурологічного підходу мистецька освіта постає як продукт культури, результат культурно-історичного розвитку людства, а вчителі та учні, не тільки як споживачі, а й як творці культури.

Культурологічний підхід $є$ ключовим у формуванні художніх орієнтацій старшокласників, оскільки спрямовує на пізнання учнями художньої культури як явища суспільного буття, ознайомлення 3 широкою панорамою художніх образів мистецтва та усвідомлення їх ціннісного значення. 
Спрямованість на осмислення духовних цінностей художньої культури забезпечує аксіологічний підхід. Мистецтво залучає людину до естетичних і художніх цінностей, примушує іiі переживати і усвідомлювати ці цінності лише за умови самовизначення в цих цінностях, «переробки» їх у власній душі. Повнота сприймання та засвоєння художніх та естетичних цінностей мистецтва залежить від контакту 3 чуттєвою сферою реципієнта. Однак, емоційність переживання художнього образу [5] повною мірою зумовлена особистісним ставленням реципієнта до нього. Звісно, вибірковість ставлень до художніх образів формується на основі досвіду спілкування 3 художніми творами, орієнтацій у царині мистецтва, поінформованості учнів щодо його різновидів, жанрів і стилів, що є основою формування художніх орієнтацій особистості. Аксіологічний підхід у формуванні художніх орієнтацій старшокласників передбачає вивчення художніх явищ з позиції їх цінності для розвитку особистості, формування іï світогляду, гуманістичного ставлення до навколишнього світу.

Комунікативний підхід, як один із системоутворюючих чинників сучасної моделі мистецької освіти, у формуванні художніх орієнтацій старшокласників орієнтує на опанування принципами, нормами, способами, уміннями міжособистісної та художньої комунікації на засадах суб'єктності та діалогу, толерантності та емпатії, критичного мислення й ціннісної інтерпретації художніх текстів. У зв’язку з цим увага фокусується на взаємозв'язках між суб'єктами художнього спілкування та внутрішнього діалогу 3 художніми творами як джерела духовного збагачення, естетичного удосконалення особистості.

Формування художніх орієнтацій старшокласників грунтується як на загальновизнаних мистецькою педагогікою методологічних підходах, та і враховує новітні методологічні орієнтири мистецької освіти. До таких методологічних підходів відносимо синергетичний, екзистениійний, феноменологічний, гедоністичний підходи. Розглянемо їх детальніше.

Визначення важливості синергетичного підходу пов'язано з тим, що формування художніх орієнтацій старшокласників $є$ не лише поступовим, лінійним, безконфліктним процесом, а й супроводжується складними трансформаційними змінами самосвідомості учня, передбачає самопізнання та самовиховання. Це обумовлює важливість процесів самоорганізації, які пояснює та виявляє синергетика (з 
грецьк. synergetikos («со»- «спільно» і «ергос» - «дія»). Синергетика пояснює хаотичний рух як можливість самоорганізації. Особливості хаотичного руху всередині системи як створення можливостей ii самоорганізації виявив німецький вчений Г. Хакен. Він довів, що неупорядкованість (хаотичність) є не тимчасовий недолік, який потрібно подолати, а нормальний стан природних, соціальних і психічних явищ i процесів, що самоорганізуються і саморозвиваються [8]. Саме з таких позицій вченіпедагоги (О. Бочкарьов, С. Клепко, В. Кремень, В. Кушнір, М. Поташник та ін.) обгрунтовують доцільність синергетичного підходу в педагогічних дослідженнях. Цей підхід визначає множинність нелінійних законів та варіантність вибору шляхів самоорганізації в педагогічному процесі. Це створення умов i надання широких можливостей кожному суб'єкту освітнього процесу щодо самоорганізації та саморозвитку, стимулювання до самостійного і відповідального прийняття рішень, визначення індивідуальної траєкторії освіти, темпу навчання, творчих завдань та ін.

Синергетичний підхід має особливе значення в мистецькій освіті, оскільки художній творчості, художньому мисленню завжди притаманний інтуїтивний пошук, неформальна логіка. Мистецька освіта, що інтегрує різноманітні художні знання, уявлення, цінності, 3 позиції синергетичного підходу має допомогти учневі в самоорганізації цих знань, уявлень, цінностей.

Так, на початковому етапі формування художніх орієнтацій старшокласник заглиблюється у безмежний світ художньої культури. Багатоманітність мистецьких явищ створює певний хаос у його свідомості. Систематичність мистецького навчання, художня комунікація з приводу мистецьких вражень та ін. сприяє упорядкуванню думок школяра, формуванню художнього мислення, критичної оцінки, визначенню власних уподобань та художніх орієнтацій в культурі, а також усвідомлення та окреслення шляхів власного саморозвитку в художній творчості.

Акцентуація саморозвитку старшокласника в процесі формування його художніх орієнтацій обумовлює виокремлення екзистенційного підходу у дослідженні означеної проблеми. Зазначимо, що екзисенційний підхід (від лат. exsistentia - існування) у педагогіці грунтується на ідеях філософського екзистенціалізму (філософії існування) повернення людини до самої себе, пізнання внутрішнього світу, відкриття «інтимної 
самості» (М. Бердяєв, М. Гайдеггер, С. К’єркегор, Р.Марсель, Ж.-П. Сартр, К. Ясперс та ін.).

У формуванні художніх орієнтацій старшокласників екзистенційний підхід зумовлює визнання свободи самовизначеності учня у світі художньої культури, звернення до власного внутрішнього життя, безпосередніх переживань художніх образів, що відкривають вищі смисли існування людини та ії відносини зі світом.

Формування художніх орієнтацій старшокласників передбачає особистісне сприймання художніх образів учнями. 3 огляду на це, постає необхідність виокремлення феноменологічного підходу (від грецьк. phainomenol - «те, що 3’являється» та logos - «вчення»), що дає змогу виявляти акти свідомості у сприйнятті художнього твору, передбачає урахування особливостей неповторно-індивідуального досвіду сприйняття мистецтва. Феноменологічний підхід орієнтує на те, що художній твір переживається людиною більш реально, якщо вона сама шукає смисл художнього твору і цей смисл у нього вкладає, а не отримує його від іншого. Це акцентує суб'єктивний смисл художніх орієнтацій.

Вивчення явищ художньої культури є неможливим без отримання насолоди від спілкування з художніми творами. Акцентує роль естетичного задоволення у вивченні мистецтва гедоністичний підхід (від грецьк. hedone -задоволення). Відчуття краси, переживання гармонії, досконалості, усвідомлення прекрасного як духовного піднесення - неодмінні характеристики художніх орієнтацій. Поза гедоністичним ставленням процес формування художніх орієнтацій неможливий, як і повноцінне сприйняття художніх творів, різновидів мистецтва.

Формування художніх орієнтацій старшокласника передбачає не лише повноцінне сприйняття творів мистецтва, визначення пріоритетів у художній культурі, а й самовизначеність школяра в художньо-творчій діяльності та самореалізацію в ній. Сферу практичної творчої діяльності учня, що забезпечує реалізації його творчих можливостей визначає діяльнісний підхід. Він забезпечує старшокласнику вільний вибір виду художньої творчості, відповідно до власних здібностей, інтересів, нахилів, та досягнення позитивних змін у саморозвитку, самореалізації.

Висновки. Отже, формування художніх орієнтацій старшокласників є складний і багатогранний процес, що враховує як традиції мистецької освіти так і нові ідеї іiі 
розвитку. Сучасні методологічні підходи формування художніх орієнтацій (особистісний, культурологічний, аксіологічний, комунікативний, синергетичний, екзистенційний, феноменологічний, гедоністичний, діяльнісний) спрямовують педагогічний процес на розвиток духовного світу молоді шляхом самовизначення в художній культурі та саморозвитку і самореалізації в художній творчості.

\section{References}

1. Kraevskyi V. V. Obshchye osnovy pedahohyky [General Fundamentals of Pedagogy]: uchebnyk. - Moskva: Yzd. tsentr «Akademyia», 2003. 256 p.

2. Otych O. M. Mystetstvo u rozvytku indyvidualnosti pedahoha: istorychnyi $i$ metodolohichnyi aspekty [Art in the development of teacher's individuality: historical and methodological aspects]: monohrafiia/ za nauk. red. I. A. Ziaziuna. - Chernivtsi: Zelena Bukovyna, 2009. 440 p.

3. Padalka H. M. Pedahohika mystetstva (Teoriya $i$ metodyka vykladannya mystets'kykh dystsyplin) [Pedagogy of art (Theory and methods of teaching art subjects) ]. Kyiv: Osvita Ukrayiny, 2008. 274 p.

4. Pankiv L. I. Formuvannia khudozhnikh oriientatsii starshoklasnykiv yak vektor dukhovnoho rozvytku osobystosti [Formation of artistic orientations of pupils as a vector of spiritual development of personality]. Mystetstvo ta osvita. 2016. No. 1 (79). P. 16-20.

5. Pet'ko L. V. Vyhovnyj $i$ profesijnyj aspekty muzychno-pedagogichnoi' sprjamovanosti navchannja inozemnoi' movy studentiv VNZ u systemi muzychnopedagogichnoi' osvity [Educational and professional aspects of music-pedagogical orientation of foreign language teaching for students in the system of music-pedagogical training]. Muzyka ta osvita. 2013. № 3. C. 14-18.

6. Rudnyts'ka O. P. Pedahohika: zahal'na ta mystets'ka: navch. posibn. [Pedagogy: General and artistic]. Ternopil: Navchalna knyha - Bohdan, 2005. 360 p.

7. Dryapika V.I. Teoriya $i$ praktyka formuvannya tsinnisnykh oriyentatsiy pedahoha-muzykanta [Theory and practice of formation of value orientations in the Music teacher]. -Kirovohrad, Uzhhorod, «Lira», 2000. 228 p.

8. Khaken H. Synerhetyka [Synergetics]. Moskva: Myr, 1980. 404 p.

\section{Translation of the Title, Name and Abstract to Author's language}

\section{УДК 37.013.73}

Паньків Л. І. Формування художніх оріснтацій старшокласників у контексті сучасних методологічних підходів.

У статті висвітлюється проблематика мистецького навчання старшокласників. Визначено значення мистецької освіти у формуванні особистості, іiі світогляду, духовного світу. Розглянуто сутність і значення художніх орієнтацій особистості. 
Визначено сучасні методологічні підходи формування художніх орієнтацій старшокласників. Доведено, що формування художніх орієнтацій старшокласників відкриває нові можливості для духовного розвитку молоді на шляху використання мистецтва як засобу особистісного зростання.

Ключові слова: художня культура, мистецтво, мистецьке навчання, художні орієнтації, методологічні підходи, цінності, старшокласники.

\section{Література}

1. Краевский В. В. Общие основы педагогики: учебник. Москва: Изд. центр «Академия», 2003. 256 с.

2. Отич О. М. Мистецтво у розвитку індивідуальності педагога: історичний i методологічний аспекти: монографія/ за наук. ред. І. А. Зязюна. - Чернівці: Зелена Буковина, 2009. 440 с.

3. Падалка Г. М. Педагогіка мистецтва (Теорія i методика викладання мистецьких дисциплін). - Київ: Освіта України, 2008. 274 с.

4. Паньків Л. І. Формування художніх орієнтацій старшокласників як вектор духовного розвитку особистості. Мистецттво та освіта. 2016. № 1 (79). С. 16-20.

5. Петько Л. В. Виховний i професійний аспекти музично-педагогічної спрямованості навчання іноземної мови студентів ВНЗ у системі музично-педагогічної освіти. Музика та освіта:: науково-метод.журнал / засн. МОН України, НАПН України, Київська дитяча академія мистецтв ; гол.ред. Л. М. Масол. - Київ: Педагогічна думка, 2013. № 3. С. 14-18.

6. Рудницька О. П. Педагогіка: загальна та мистецька: навч. посібник. Тернопіль: Навчальна книга - Богдан, 2005. 360 с.

7. Дряпіка В. І. Теорія і практика формування ціннісних орієнтацій педагогамузиканта. - Київ-Кіровоград, Ужгород, «Ліра», 2000. 228 с.

8. Хакен Г. Синергетика. - Москва: Мир, 1980. 404 с. 